\title{
Short Simple Linear Peptides Mimic Antimicrobial Complex Cyclodecapeptides Based on the Putative Pharmacophore
}

\section{Cuiping Guo', Long Pan', Shengwei Xiao', Heru Chen ${ }^{1,2 *}$ and Zhenyou Jiang ${ }^{3}$}

${ }^{1}$ Institute of Traditional Chinese Medicine and Natural Product, College of Pharmacy, Jinan University Guangzhou 510632, People's Republic of China ${ }^{2}$ Guangdong Province Key Laboratory of Pharmacodynamic Constituents of TCM and New Drugs Research, Guangzhou 510632, People's Republic of China ${ }^{3}$ Department of Microbiology and Immunology, Jinan University, Guangzhou 510632, People's Republic of China

\begin{abstract}
The sequence, -D-Tyr-Pro-Trp-D-Phe- has been identified from Loloatin C as a promising pharmacophore model for developing new antimicrobial peptides. Most of the linear peptides designed based on this sequence exhibits strong antimicrobial activities against Gram-positive bacteria $S$. aureus, S. albus and Gram-negative bacteria $E$. coli strains with MIC values ranging from 15.6 to $62.5 \mu \mathrm{g} / \mathrm{mL}$, although they are inactive against fungus $C$. albicans, multi-drug resistant bacterial MRSA and K. pneumoniae. The linear hexapeptide, H-Asp-D-Tyr-Pro-Trp-D-Phe-Asn-OH (L1) is confirmed the most active peptide among them. L1 possesses stable $\alpha$-helix domain conformation which is similar to Loloatin $\mathrm{C}$ in membrane mimetic solution. All the tested peptides demonstrate low hemolytic toxicity to rabbit red blood cells with $\mathrm{EC}_{50}$ values higher than $120 \mu \mathrm{g} / \mathrm{mL}$ and low cytotoxicity to mouse fibroblast cells. The successful simplication of Loloatin $\mathrm{C}$ to a short linear peptide simplifies the synthetic process and lowers costs of production. The discussion of structure-activity relationship is also included.
\end{abstract}

Keywords: Antimicrobial peptide; Pharmacophore similarity; Drug design; Molecular simplification

Abbreviations: AMPs: Antimicrobial Peptides; Asp: Aspartyl; Tyr: Tyrosyl; Pro: Prolyl; Trp: Tryptphanyl; Phe: Phenylalanyl; Asn: Asparaginyl; Leu: Leucyl; Orn: ornithyl; Tic: 1,2,3,4-Tetrahydroisoquinoline-3-formoxyl; Pip: Piperidine-2formoxyl;HATU:O-(7-azabenzotriazolyl)-1,1,3,3-tetramethyluronium hexafluorophosphate; HOAt: 1-hydroxy-7-azabenzotriazole; TMP: 2,4,6-trimethylpyridine; TFA: Trifluoroacetic; TFE: Trifluoroethanol; TIF: Triisopropylsilane; ESI-MS: Electrospray Ionization Mass Spectrometry; HRMS: High-Resolution Mass Spectrometer; $t_{\mathrm{R}}$ Chromatographic Retention Time; Å: Angstrom

\section{Introduction}

During the last few decades, the problem of bacterial resistance to antibiotics becomes a major issue in human health and the construction of new therapeutic agents to combat micro-organisms resistant to traditional antibiotics is nowaday an urgent task [13]. Fortunately, antimicrobial peptides (AMPs), secreted by innate immune system of many organisms, have been identified as a new promising generation of antibiotics because of their rapid and broadspectrum antimicrobial properties, ability to kill multidrug-resistant bacteria, and a low propensity for the development of resistance [46]. Interestingly, several cyclodecapeptides including Gramicidin S [7], Tyrocidine A [8], and Loloatin C [9-12] (Figure 1), belonging to AMPs, have received a great deal of attentions due to their highly desirable mechanism targeting on the bacterial membrane, which the bacteria are hard to develop resistance toward them [4].

Despite all the potential advantages over conventional antibiotics mentioned above, pharmaceutical development of these cyclopeptides into therapeutic agents has been limited by the large size of these peptides, the corresponding high production cost to synthesize in bulk, and cytotoxicity to red blood cells. To address these issues, perhaps one effective pathway is to simplify the complex cyclopeptide into small linear peptide based on the pharmacophore. However, the definition of pharmacophore for an active cyclopeptide is not easy. Loloatin C, a cyclic decapeptide isolated from laboratory cultures of a tropical marine bacterium collected from the Great Barrier Reef off the southern coast of Papua New Guinea. Previously, the total synthesis of Loloatin C
[13] and its solution conformation studies have been completed [11]. And we tried to identify the pharmacophore of Loloatin $\mathrm{C}$ by "sliding window" approach $[14,15]$. Through narrowing Loloatin C into three cyclic hexapeptides and comparing their antimicrobial properties, it was deduced that the sequence-D-Tyr-Pro-Trp-D-Phe- was essential to its antimicrobial activities, and might be the pharmacophore of Loloatin C [16]. Whether if it is true has not been confirmed. Should

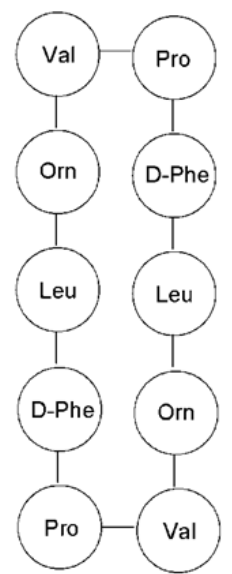

Gramicidin S

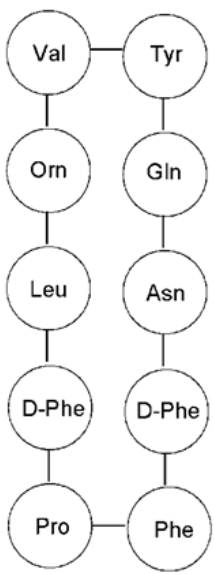

Tyrocidine S

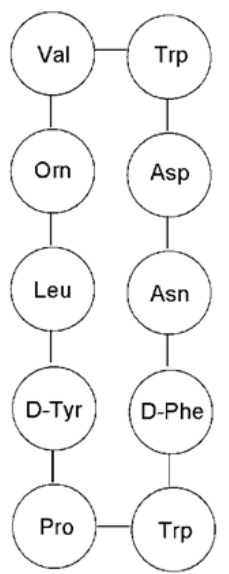

Loloatin C
Figure 1: Chemical structures of Gramicidin S, Tyrocidine S, and Loloatin C.

*Corresponding author: Heru Chen, Huangpu Avenue West 601, Institute of Traditional Chinese Medicine and Natural Product, College of Pharmacy, Jinan University, Guangzhou 510632, P. R. China, Tel: +86-20-38375299; Fax: +86-2085221559; E-mail: thrchen@jnu.edu.cn

Received December 02, 2013; Accepted January 10, 2014; Published January 10,2014

Citation: Guo C, Pan L, Xiao S, Chen H, Jiang Z (2014) Short Simple Linear Peptides Mimic Antimicrobial Complex Cyclodecapeptides Based on the Putative Pharmacophore. Med chem 4: 322-329. doi:10.4172/2161-0444.1000159

Copyright: (c) 2014 Guo C, et al. This is an open-access article distributed under the terms of the Creative Commons Attribution License, which permits unrestricted use, distribution, and reproduction in any medium, provided the original author and source are credited. 
the target molecule be in cyclic format or in linear state? We prefer to the latter choice because the synthetic process may be simplified dramatically and the cytotoxicity to red blood cells may be lowered down. Herein, we describe our effort in the design and synthesis of a series of linear peptides containing the sequence -D-Tyr-Pro-TrpD-Phe- to mimic Loloatin C and the study of their structure-activity relationship.

\section{Experimental}

\section{Materials and methods}

Materials: $\mathrm{N}, \mathrm{N}$-Dimethylformamide (DMF) of analytical grade was dried over $4 \AA$ molecular sieves. Methanol $(\mathrm{MeOH})$ of analytical grade and dichloromethane (DCM) of analytical grade were freshly distilled from $\mathrm{CaH}_{2}$ and stored over $4 \AA$ molecular sieves. Piperidine was dried over $\mathrm{KOH}$ and distilled immediately prior to use. HPLCgrade acetonitrile was of the highest purity available from commercial sources. Other commercial reagents and solvents were used as received. Fmoc-protected amino acids, Rink Amide AM Resin (cross-linking $1 \%$ DVB, bead size $100-200$ mesh, loading $0.61 \mathrm{mmol} / \mathrm{g}$ ), HATU and HOAt were obtained from GL Bio. Chem. Ltd. (Shanghai, China).

Isolation and Structural Confirmation: Analytical reversed phase high performance liquid chromatograph (RP-HPLC) was used to determine purities of peptides and was carried out on LC-100 chromatograph with a Cosmosil packed column $5 \mathrm{C}_{18}$-MS- II (4.6 $\mathrm{mm} \times 250 \mathrm{~mm}, 5 \mu \mathrm{m}$ ) using gradients of acetonitrile/0.1\% TFA in water with a flow rate of $1.0 \mathrm{~mL} / \mathrm{min}$. UV-detection: $\lambda=214 \mathrm{~nm}$. Purity for all compounds synthesized and tested was at or above $95 \%$ unless otherwise noted. Preparative RP-HPLC was performed by using a $5 \mathrm{C}_{18}$ MS- II $(20 \mathrm{~mm} \times 250 \mathrm{~mm}, 5 \mu \mathrm{m})$ column on LC-100 chromatograph using gradients of acetonitrile/0.1\% TFA in water with a flow rate of $8.0 \mathrm{~mL} / \mathrm{min}$. ESI-MS was recorded on Finnigan LCQ Advantage MAX mass spectrometer (Thermo Fisher Scientific., USA). HRMS spectra were obtained on Vevo G2 Q-Tof mass spectrometer (Waters, USA).

General Procedure for solid phase peptide synthesis: The Rink amide resins $0.33 \mathrm{~g}(0.2 \mathrm{mmol})$ was placed in $15-\mathrm{mL}$ peptide synthesizer. The resins were swelled with DCM $(3 \mathrm{~mL})$ to ensure that all the resin beads were immersed for 20 to $30 \mathrm{~min}$. DCM was filtrated under vacuum, and the resins were treated with $25 \%$ piperidine in DMF $(\mathrm{v} / \mathrm{v})$ to release the free amino groups. Peptide assemblage was pursued as described in literatures $[11,17,18]$. All the coupling reactions were carried out in DMF $(1.5 \mathrm{~mL})$ using the Fmoc amino acid derivative ( 3 eq) and HATU (2.9 eq)/HOAt (2.9 eq) /TMP (3.0 eq). The mixture was agitated in shaker. Usually, the coupling reaction was allowed to run for 2-3 h. The completion of the reaction was monitored by the Kaiser test [19]; except for the coupling of Pro, Pip and Tic, which were detected by Chloranil test [20]. Removal of the terminal Fmoc group was effected with two treatments of $25 \%$ piperidine in DMF, in which the scheduled times were 25 and 5 min respectively. After all the amino acids was assembled, the linear peptide-linked resins were washed at least three times with DCM, and dried thoroughly under vacuum. DMF was then added to swell the resins for 10 mins. Afterwards, the resins were treated twice with TFA:TIS: $\mathrm{H}_{2} \mathrm{O}(95: 2.5: 2.5, V / V / V)$ at room temperature for $3 \mathrm{~h}$. All the filtrates were collected and concentrated under vacuum at room temperature. Peptides were precipitated from cold ether solution. The crude peptides were collected and purified by preparative RP-HPLC. Fractions containing the required products were collected and subjested to lyophilisation to give the pure product. All the synthesized products were purified to homogeneity by preparative RP-HPLC before characterization. The structures of all the synthesized peptides were identified by ESI-MS and HRMS.
Synthesis of H-Asp-D-Tyr-Pro-Trp-D-Phe-Asn-OH (L1): Compound L1 was prepared according to the above general procedure using resins $(0.33 \mathrm{~g}, 0.200 \mathrm{mmol})$, and was purified on preparative RP-HPLC. The eluent was: acetonitrile (A), $0.1 \%$ TFA in water (B); gradient: $20 \%$ A to $40 \%$ A within 50 minutes; flow rate: $8.0 \mathrm{~mL} / \mathrm{min}$. The pure compound was obtained as slightly yellowish solid. Yield 0.0706 g, $42 \%$. Purity: $95 \%$. ESI-MS $(m / z)$ : $[\mathrm{M}+\mathrm{H}]^{+}$calcd for $\mathrm{C}_{42} \mathrm{H}_{49} \mathrm{~N}_{8} \mathrm{O}_{11}$, 841.3; found 841.8. $[\mathrm{M}+2 \mathrm{H}]^{++}$calcd for 432.2; found, 432.7. [M + $\mathrm{Na}]^{+}$calcd for $\mathrm{C}_{42} \mathrm{H}_{48} \mathrm{~N}_{8} \mathrm{O}_{11} \mathrm{Na}, 863.3$; found, 863.8. [M+K] $]^{+}$calcd for $\mathrm{C}_{42} \mathrm{H}_{48} \mathrm{~N}_{8} \mathrm{O}_{11} \mathrm{~K}$, 879.3; found, 879.9. [M-H] ' calcd for $\mathrm{C}_{42} \mathrm{H}_{47} \mathrm{~N}_{8} \mathrm{O}_{11}, 839.3$; found, 839.8. HRMS $(m / z)$ : $[\mathrm{M}+\mathrm{H}]^{+}$calcd for $\mathrm{C}_{42} \mathrm{H}_{49} \mathrm{~N}_{8} \mathrm{O}_{11}, 841.35153$; found, 841.35416.

Synthesis of H-Asp-L-Leu-D-Tyr-Pro-Trp-D-Phe-Asn-OH (L1.1): Compound L1.1 was prepared according to the general procedure using resins $(0.332 \mathrm{~g}, 0.203 \mathrm{mmol})$, and was purified on preparative RP-HPLC. The eluent was: acetonitrile (A), 0.1\% TFA in water (B); gradient: $10 \%$ A to $42 \%$ A within 70 minutes; flow rate: 8.0 $\mathrm{mL} / \mathrm{min}$. The pure compound was obtained as slightly yellowish solid. Yield 0.0858 g, $45 \%$. Purity 95\%. ESI-MS $(\mathrm{m} / z):[\mathrm{M}+\mathrm{H}]^{+}$calcd for $\mathrm{C}_{48} \mathrm{H}_{60} \mathrm{~N}_{9} \mathrm{O}_{12}$, 954.4; found, 954.8. [M-H] calcd for $\mathrm{C}_{48} \mathrm{H}_{58} \mathrm{~N}_{9} \mathrm{O}_{12}, 952.4$; found, 952.9. HRMS $(\mathrm{m} / z):[\mathrm{M}+\mathrm{H}]^{+}$calcd for $\mathrm{C}_{48} \mathrm{H}_{60} \mathrm{~N}_{9} \mathrm{O}_{12}, 954.43559$; found, 954.43776 .

Synthesis of H-Asp-L-Orn-D-Tyr-Pro-Trp-D-Phe-Asn-OH (L1.2): Compound L1.2 was prepared according to the general procedure using resins $(0.331 \mathrm{~g}, 0.202 \mathrm{mmol})$, and was purified by preparative RP-HPLC. The eluent was: acetonitrile (A), $0.1 \%$ TFA in water (B); gradient: $20 \%$ A to $40 \%$ A within 40 minutes; flow rate: $8.0 \mathrm{~mL} / \mathrm{min}$. The pure compound was obtained as yellowish solid. Yield $0.0814 \mathrm{~g}$, $42 \%$. Purity $96 \%$. ESI-MS $(\mathrm{m} / \mathrm{z}):[\mathrm{M}+\mathrm{H}]^{+}$calcd for $\mathrm{C}_{47} \mathrm{H}_{59} \mathrm{~N}_{10} \mathrm{O}_{12}, 955.4$; found, 955.8. $[\mathrm{M}+2 \mathrm{H}]^{++}$calcd for $\left[\mathrm{C}_{47} \mathrm{H}_{60} \mathrm{~N}_{10} \mathrm{O}_{12}\right] / 2$, 478.2; found, 478.6. [M-H] calcd for $\mathrm{C}_{47} \mathrm{H}_{57} \mathrm{~N}_{10} \mathrm{O}_{12}$, 953.4; found, 953.9. HRMS $(\mathrm{m} / z)$ : $[\mathrm{M}+\mathrm{H}]^{+}$calcd for $\mathrm{C}_{47} \mathrm{H}_{59} \mathrm{~N}_{10} \mathrm{O}_{12}, 955.43084$; found, 955.43181 .

Synthesis of H-Asp-D-Tyr-Pip-Trp-D-Phe-Asn-OH (L2): Compound L2 was prepared according to the general procedure using resins $(0.331 \mathrm{~g}, 0.202 \mathrm{mmol})$, and was purified by preparative RP-HPLC. The eluent was: acetonitrile (A), $0.1 \%$ TFA in water (B); gradient: $25 \%$ A to $40 \%$ A within 70 minutes; flow rate: $8.0 \mathrm{~mL} / \mathrm{min}$. The pure compound was obtained as yellowish solid. Yield 0.0811 g, 47\%. Purity 95\%. ESI-MS $(\mathrm{m} / \mathrm{z})$ : $[\mathrm{M}+\mathrm{H}]^{+}$calcd for $\mathrm{C}_{43} \mathrm{H}_{51} \mathrm{~N}_{8} \mathrm{O}_{11}$, 855.4; found, 855.7. $[\mathrm{M}+\mathrm{Na}]^{+}$calcd for $\mathrm{C}_{43} \mathrm{H}_{50} \mathrm{~N}_{8} \mathrm{O}_{11} \mathrm{Na}$, 877.4; found, 877.8. [M-H] calcd for $\mathrm{C}_{43} \mathrm{H}_{49} \mathrm{~N}_{8} \mathrm{O}_{11}$, 853.4; found, 853.8. HRMS $(\mathrm{m} / \mathrm{z})$ : $[\mathrm{M}+\mathrm{H}]^{+}$calcd for 855.36718 , found, 855.36797.

Synthesis of H-Asp-L-Leu-D-Tyr-Pip-Trp-D-Phe-Asn-OH (L2.1): Compound L2.1 was prepared according to the general procedure using resins $(0.332 \mathrm{~g}, 0.203 \mathrm{mmol})$, and was purified by preparative RP-HPLC. The eluent was: acetonitrile (A), 0.1\% TFA in water (B); gradient: $25 \% \mathrm{~A}$ to $42 \% \mathrm{~A}$ within 70 minutes; flow rate: $8.0 \mathrm{~mL} / \mathrm{min}$. The pure compound was obtained as yellowish solid. Yield 0.0727 g, 37\%. Purity 95\%. ESI-MS $(\mathrm{m} / \mathrm{z})$ : $[\mathrm{M}+\mathrm{H}]^{+}$calcd for $\mathrm{C}_{49} \mathrm{H}_{62} \mathrm{~N}_{9} \mathrm{O}_{12}$, 968.5; found, 968.9. [M+Na] ${ }^{+}$calcd for $\mathrm{C}_{49} \mathrm{H}_{61} \mathrm{~N}_{9} \mathrm{O}_{12} \mathrm{Na}$, 990.5; found, 990.9. [M-H] calcd for $\mathrm{C}_{49} \mathrm{H}_{60} \mathrm{~N}_{9} \mathrm{O}_{12}$, 966.5; found, 966.9. HRMS $(\mathrm{m} / z)$ : $[\mathrm{M}+\mathrm{H}]^{+}$calcd for $\mathrm{C}_{49} \mathrm{H}_{62} \mathrm{~N}_{9} \mathrm{O}_{12}, 968.45334$; found 968.45626.

Synthesis of H-Asp-D-Tyr-Tic-Trp-D-Phe-Asn-OH (L3): Compound L3 was prepared according to the general procedure using resins $(0.331 \mathrm{~g}, 0.202 \mathrm{mmol})$, and was purified by preparative RP-HPLC. The eluent was: acetonitrile (A), $0.1 \%$ TFA in water (B); gradient: $25 \%$ A to $40 \%$ A within 60 minutes; flow rate: $8.0 \mathrm{~mL} / \mathrm{min}$. 
The pure compound was obtained as yellowish solid. Yield $0.0547 \mathrm{~g}$, $30 \%$. Purity 95\%. ESI-MS $(m / z):[\mathrm{M}+\mathrm{H}]^{+}$calcd for $\mathrm{C}_{47} \mathrm{H}_{51} \mathrm{~N}_{8} \mathrm{O}_{11}, 903.4$; found, 903.8. $[\mathrm{M}+\mathrm{Na}]^{+}$calcd for $\mathrm{C}_{47} \mathrm{H}_{50} \mathrm{~N}_{8} \mathrm{O}_{11} \mathrm{Na}$, 925.4; found, 925.8. $[\mathrm{M}+\mathrm{K}]^{+}$calcd for $\mathrm{C}_{47} \mathrm{H}_{50} \mathrm{~N}_{8} \mathrm{O}_{11} \mathrm{~K}, 941.4$; found, 941.8. [M-H] calcd for $\mathrm{C}_{47} \mathrm{H}_{49} \mathrm{~N}_{8} \mathrm{O}_{11}$, 901.4; found, 901.8. HRMS $(\mathrm{m} / z)$ : $[\mathrm{M}+\mathrm{H}]^{+}$calcd for $\mathrm{C}_{47} \mathrm{H}_{51} \mathrm{~N}_{8} \mathrm{O}_{11}$ 903.36718, found: 903.36987.

Synthesis of H-Asp-L-Leu-D-Tyr-Tic-Trp-D-Phe-Asn-OH (L3.1): Compound L3.1 was prepared according to the general procedure using resins $(0.331 \mathrm{~g}, 0.202 \mathrm{mmol})$, and was purified by preparative RP-HPLC. The eluent was: acetonitrile (A), $0.1 \%$ TFA in water (B); gradient: $20 \%$ A to $45 \%$ A within 70 minutes; flow rate: $8.0 \mathrm{~mL} / \mathrm{min}$. The pure compound was obtained as yellowish solid. Yield $0.0718 \mathrm{~g}, 35 \%$. Purity 95\%. ESI-MS $(\mathrm{m} / \mathrm{z})$ : $[\mathrm{M}+\mathrm{H}]^{+}$calcd for $\mathrm{C}_{53} \mathrm{H}_{62} \mathrm{~N}_{9} \mathrm{O}_{12}, 1016.4$; found, 1016.9. [M-H] calcd for $\mathrm{C}_{53} \mathrm{H}_{60} \mathrm{~N}_{9} \mathrm{O}_{12}$, 1014.4; found, 1014.9. HRMS $(\mathrm{m} / z)$ : $[\mathrm{M}+\mathrm{H}]^{+}$calcd for 1016.45124; found, 1016.45068 .

Synthesis of H-Asp-L-Orn-D-Tyr-Tic-Trp-D-Phe-Asn-OH (L3.2): Compound L3.2 was prepared according to the general procedure using resins $(0.331 \mathrm{~g}, 0.202 \mathrm{mmol})$, and was purified by preparative RP-HPLC. The eluent was: acetonitrile (A), 0.1\% TFA in water (B); gradient: $25 \%$ A to $32 \%$ A within 50 minutes; flow rate: 8.0 $\mathrm{mL} / \mathrm{min}$. The pure compound was obtained as yellowish solid. Yield 80.2 mg, 39\%. Purity 96\%. ESI-MS (m/z): $[\mathrm{M}+\mathrm{H}]^{+}$calcd for $\mathrm{C}_{52} \mathrm{H}_{61} \mathrm{~N}_{10} \mathrm{O}_{12}$, 1017.4; found, 1017.9. $[\mathrm{M}+2 \mathrm{H}]^{++}$calcd for $\left[\mathrm{C}_{52} \mathrm{H}_{62} \mathrm{~N}_{10} \mathrm{O}_{12}\right] / 2,509.2$; found, 509.7; [M-H] calcd for $\mathrm{C}_{52} \mathrm{H}_{59} \mathrm{~N}_{10} \mathrm{O}_{12}, 1015.4$; found, 1015.9. HRMS $(\mathrm{m} / z):[\mathrm{M}+\mathrm{H}]^{+}$calcd for $\mathrm{C}_{52} \mathrm{H}_{61} \mathrm{~N}_{10} \mathrm{O}_{12}, 1017.44649$; found, 1017.45002.

Antibacterial assay: Before each experiment, all materials were autoclaved at $121^{\circ} \mathrm{C}$ for $30 \mathrm{~min}$ to ensure sterility. The antibacterial activities of each peptides were determined against four strains of Gram-positive bacteria (C. albicans ATCC 10231, S. aureus ATCC 6538, S. albus ATCC 8799, and MRSA ATCC 43300) and three strains of Gram-negative bacteria (E. coli ATCC 8099, K. pneumonia ATCC 13883, and P. aeruginosa ATCC PA9027). C. albicans ATCC 10231 strains was cultured in Malt-Extract (ME) medium and others were cultured in Nutrient-Broth (NB) medium. Antibacterial susceptibility was measured as the minimal inhibitory concentration (MIC), which was determined in 96-well plates by a standard two-fold microdilution method as described previously [21]. Peptide stock solutions at 250 $\mu \mathrm{g} / \mathrm{mL}$ in sterile deionized water containing $0.2 \%(\mathrm{w} / \mathrm{v})$ bovine serum albumin (BSA) and $0.01 \%(\mathrm{v} / \mathrm{v})$ acetic acid were prepared, and working solutions were prepared by two-fold serial dilution of the stock solution. Bacteria were incubated to logarithmic phase at $37^{\circ} \mathrm{C}$ and diluted with fresh medium to $10^{6} \mathrm{CFU} / \mathrm{mL}$. $50 \mu \mathrm{L}$ of two-fold serial dilutions of the peptide ranging from $250 \mu \mathrm{g} / \mathrm{mL}$ to $1.95 \mu \mathrm{g} / \mathrm{mL}$ were prepared in 96-well plates and mixed with $50 \mu \mathrm{L}$ of bacteria inoculum. Cultures without added peptides were used as the positive control, and sterile deionized water was used as the negative control. Plates were incubated at $37^{\circ} \mathrm{C}$ for $24 \mathrm{~h}$ and the MIC at which no visible growth occurred was recorded. The tests were performed at least three times.

The bacteria were incubated with peptide L1 in concentration of $125 \mu \mathrm{g} / \mathrm{mL}$ for $24 \mathrm{~h}$ at $37^{\circ} \mathrm{C}$, and the culture medium was used as control. The bacteria was stained using acridine orange and ethidium bromide for $15 \mathrm{~min}$ in the dark, and the samples were visualized using 510 META DUO SCAN fluorescence microscopy. Acridine orange penetrated the plasma membrane of live and dead cells, and stained live and dead cells green. Ethidium bromide did not penetrate the plasma, and stained only dead cells orange.
Cytotoxicity assay: The cytotoxic assay of the peptide was evaluated by Cell Counting Kit-8 (CCK-8) assay on mouse fibroblast cells NCTC clone 929 (L cell, L-929, derivative of strain L). The cells were cultured in minimum essential medium (MEM) supplemented with $10 \%$ (v/v) of fetal bovine serum, 100 units $/ \mathrm{mL}$ penicillin and $100 \mathrm{mg} / \mathrm{mL}$ streptomycin, grown at $37^{\circ} \mathrm{C}$ in a $5 \% \mathrm{CO}_{2}$ humidified environment. 100 $\mu \mathrm{L}$ of the cells were seeded at a density of $7 \times 10^{3}$ cells per well in 96-well plates and incubated at $37^{\circ} \mathrm{C}$ for $24 \mathrm{~h} .10 \mu \mathrm{L}$ of two-fold serial dilutions of the peptides ranging from $250 \mu \mathrm{g} / \mathrm{mL}$ to $1.95 \mu \mathrm{g} / \mathrm{mL}$ was added. After 24,48 and $72 \mathrm{~h}$ incubation with the peptide, $10 \mu \mathrm{L}$ of CCK- 8 reagent was added to each well, and incubated for $2 \mathrm{~h}$. The absorbance was estimated at $450 \mathrm{~nm}$. Cells cultured in the medium without adding any material were used as the negative control. The tests were performed in triplicate. Results were expressed as a percentage of the inhibition rate for viable cells.

Hemolysis assay: Hemolytic assay of the peptides was carried out as described previously [22]. The rabbit blood was freshly drawn and anticoagulated by heparin. The red blood cells were collected by centrifugation and repeatedly washed with phosphate-buffered saline (PBS) until the appearance of a clear supernatant. The red blood cells were diluted with PBS to a final concentration of $1 \%$ (v/v). $20 \mu \mathrm{L}$ of the peptides ranging from $250 \mu \mathrm{g} / \mathrm{mL}$ to $1.95 \mu \mathrm{g} / \mathrm{mL}$ was prepared in 96 -well plates, and $80 \mu \mathrm{L}$ of the blood cells $1 \%(\mathrm{v} / \mathrm{v})$ was added to each well. After $1 \mathrm{~h}$ incubation at $37^{\circ} \mathrm{C}$, the plates were centrifugated at $13000 \mathrm{rpm}$ for $10 \mathrm{~min}$, and aliquots $(80 \mathrm{ml})$ of the supernatant was transferred to a fresh 96-well plate. The amount of hemoglobin released was measured at $405 \mathrm{~nm}$. The red blood cells suspended in $2 \%$ Triton $\mathrm{X}-100$ and PBS were used as the positive control and the negative control respectively. All the experiments were repeated three times. The $\mathrm{EC}_{50}$ value was defined as the mean concentration of the peptides producing $50 \%$ hemolysis in three independent experiments.

Circular Dichoism (CD) Measurements: CD spectra of the peptides were performed on a Jasco J-810 spectropolarimeter. For each sample, the spectra of both blank solution and sample solution were acquired simultaneously under identical conditions, which were measured between 190 and $250 \mathrm{~nm}$ using $0.02 \mathrm{~cm}$ path-length cell with $3.41 \mathrm{~nm}$ bandwidth, $4 \mathrm{~s}$ response time, and a scan speed of $100 \mathrm{~nm} /$ $\mathrm{min}$. The spectra were averaged from five scans at one gain. The true spectra for the samples were then derived by subtraction of the blank from the sample spectra, and were smoothed with the use of Jasco spectra analysis software. The spectra was recorded in $10 \mathrm{mM}$ sodium acetate buffer $\mathrm{NaOAc}$ and $30 \mathrm{wt} \%$ trifluoroethanol (TFE) in $10 \mathrm{mM}$ sodium acetate (30 wt-\% TFE/NaoAc) solutions. Concentrations of peptides were $20 \mathrm{mM}$.

Statistical analysis: Data are represented as the groups' mean \pm SEM (standard error of the mean). The significance of differences between groups was analysed with General Linear Model by Univariate, and followed by S-N-K test. All statistical analyses were calculated with Software SPSS version 13.0.

\section{Results}

\section{Peptide design}

In order to confirm the pharmacophore of loloatins $C$ concluding from "sliding window" approach, the sequence -D-Tyr-Pro-Trp-DPhe- was applied as a template. As shown in Table 1, a series of linear peptides mimicing the cyclodecapeptide have been designed. In entry L1, two hydrophilic amino acids, Asp and Asn were introduced in $\mathrm{N}$ and $C$-terminal respectively in order to balance the great lipophilicity caused by the sequence. Replacement of Pro in L1 with Pip (Piperidine- 
2-formoxyl) or Tic (1,2,3,4-tetrahydroisoquinoline-3-formoxyl), which was changed into L2 or L3, respectively, is to investigate the impact of ring enlargement on antimicrobial activity. Insertion of Leu and Orn in series L1, L2, and L3, respectively is in the purpose of studying the influence of the hydrophobicity and electricity on their antibacterial activity.

\section{Peptide synthesis}

The syntheses of all the linear peptides have been carried out successfully by application of a scheme reported earlier (11). As outlined in Scheme 1, the peptide chain was built from $\mathrm{C}$ to $\mathrm{N}$ by sequentially extending towards the amino terminus by the manual solid phase method using Fmoc/t-Bu strategy [23]. Rink amide AM resins were used as solid support. The first amino acid, Fmoc-Asp-O $t$ $\mathrm{Bu}$ was coupled to the resins through its side chain, which at the final step was turned into Asn. This strategy enhances the stability of the linkage between the first loading amino acid and resin, resulting in the increase of overall yield. As listed in Table 2, the overall yields for each peptide were from $30 \%$ to $47 \%$. The retention time $\left(t_{R}\right)$ of each peptide in their RP-HPLC was also presented in the table. This $t_{R}$ value may be used for comparisons of the hydrophobicity [18]. Since the stationary phase of $\mathrm{C}_{18}$-modified silica is hydrophobic and the mobile phase (water/acetonitrile) is hydrophilic, longer retention time means greater hydrophobicity. In the current case, the order of the hydrophobicity for each peptide was: $\mathrm{L} 1<\mathrm{L} 2<\mathrm{L} 3, \mathrm{~L} 1.1<\mathrm{L} 2.1<\mathrm{L} 3.1$, and $\mathrm{L} 1.2<\mathrm{L} 3.2$ respectively.

\section{Antimicrobial activities}

The antimicrobial activities of the prepared peptides against various strains of bacterial were summarized in Table 3 . The results showed that the peptides exhibited different activities against the tested bacteria. In general, all the peptides were more active against Gram-positive bacteria including S. aureus, S. albus and Gram-negative bacteria E. coli strains. However, all of them were inactive against fungus C. albicans, multi-drug resistant bacterium $M R S A$ and K. pneumoniae. Among them, peptide $\mathbf{L} \mathbf{1}$ exhibited the highest activities against Gram-positive bacteria $S$. aureus, $S$. albus and Gram-negative bacteria E. coli strains with MIC values of $15.6 \mu \mathrm{g} / \mathrm{mL}$. The antimicrobial ability of L1 to $E$. coli bacteria was also demonstrated by fluorescence staining. As shown in Figure 2, all of the bacteria were viable in the culture medium, which displayed green fluorescence; when the bacteria was treated with L1 in a concentration of $125 \mu \mathrm{g} / \mathrm{mL}(4 \times \mathrm{MIC})$, all the bacteria were killed, which were indicated by red fluorescence.

Modification of peptide by substitution of the given residue usually resulted in the change of its structural parameters, leading to the change of its biological activity [24]. As shown in Table 3, incorporation of either Pip or Tic in the position of Pro in L1 resulted in significant decrease of the antimicrobial activities (entries L2 and L3), which clearly indicated that Pro was the important residue in the sequence.

\begin{tabular}{ll}
\hline Entries & Sequence \\
\hline L1 & H-Asp-D-Tyr-Pro-Trp-D-Phe-Asn-OH \\
L1.1 & H-Asp-L-Leu-D-Tyr-Pro-Trp-D-Phe-Asn-OH \\
L1.2 & H-Asp-L-Orn-D-Tyr-Pro-Trp-D-Phe-Asn-OH \\
L2 & H-Asp-D-Tyr-Pip-Trp-D-Phe-Asn-OH \\
L2.1 & H-Asp-L-Leu-D-Tyr-Pip-Trp-D-Phe-Asn-OH \\
L3 & H-Asp-D-Tyr-Tic-Trp-D-Phe-Asn-OH \\
L3.1 & H-Asp-L-Leu-D-Tyr-Tic-Trp-D-Phe-Asn-OH \\
L3.2 & H-Asp-L-Orn-D-Tyr-Tic-Trp-D-Phe-Asn-OH \\
\hline
\end{tabular}

Table 1: Sequences of the Designed Linear Peptides.

\begin{tabular}{|c|c|c|c|}
\hline \multirow{2}{*}{ Entries } & $\mathrm{Mw} / \mathrm{M}+\mathrm{H}(\mathrm{Da})$ & \multirow{2}{*}{$t_{R}(\min )^{b}$} & \multirow{2}{*}{$\begin{array}{l}\text { Hemolytic toxicity } \\
\mathrm{EC}_{50}(\mu \mathrm{g} / \mathrm{mL})^{\mathrm{c}}\end{array}$} \\
\hline & calcd founda & & \\
\hline Loloatin C & 1336.660441336 .66123 & 53.36 & 85 \\
\hline L1 & 841.35153841 .35416 & 13.47 & 120 \\
\hline L1.1 & 954.43559954 .43776 & 23.98 & 130 \\
\hline L1.2 & 955.43084955 .43181 & 10.23 & $>250$ \\
\hline L2 & 855.36718855 .36797 & 17.08 & $>250$ \\
\hline L2.1 & 968.45334968 .45626 & 27.72 & 237 \\
\hline L3 & 903.36718903 .36987 & 21.06 & 160 \\
\hline L3.1 & 1016.451241016 .45068 & 34.25 & 135 \\
\hline L3.2 & 1017.446491017 .45002 & 16.66 & $>250$ \\
\hline
\end{tabular}

${ }^{a}$ HRMS

${ }^{b}$ Retention time was measured using analytical column (see Experimental Section) ${ }^{c} \mathrm{EC}_{50}$ was defined as the concentration of peptides producing $50 \%$ hemolysis

Table 2: Physicochemical Properties and Hemolytic Toxicities of the Peptides.

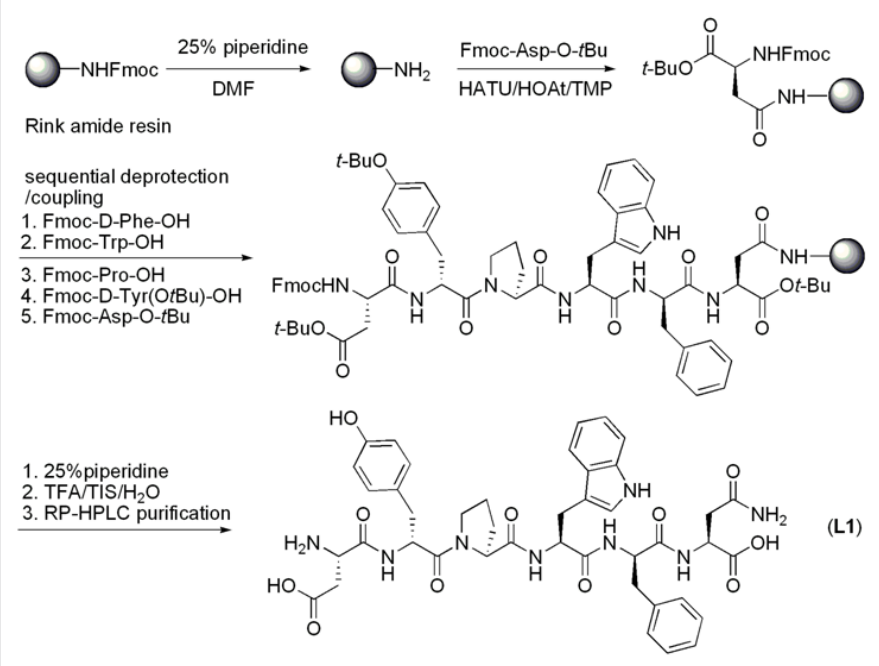

Scheme 1: Solid-Phase Synthesis of the Peptide L1.
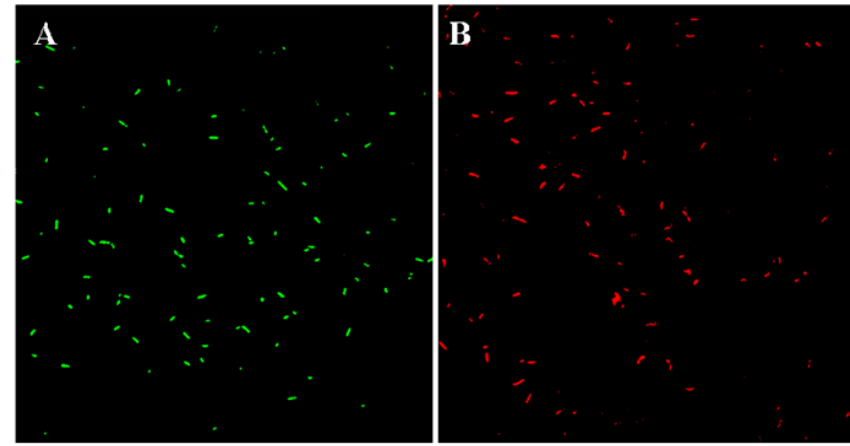

Figure 2: Indication of the viability of bacteria (E. coli ATCC 8099) by fluorescent staining. (A) blank control. (B) Treatment with peptide $\mathbf{L} 1$ at the concentration of $125 \mu \mathrm{g} / \mathrm{mL}$.

Insertion of Leu in L1 and L2 (entries L1.1 and L2.1) led to the decrease of their antimicrobial activities. However, insertion of Leu in L3 (L3.1) increase its activity. Interestingly, insertion of Orn in L1 and L3 (entries L1.2 and L3.2) resulted in the loss of activities.

\section{CD analyses}

CD spectroscopy was employed to check the secondary structure of the peptides. Generally, the amphipathic helical antimicrobial peptides adopted their helical conformations upon interactions with the 
membrane. In the present study, both $10 \mathrm{mM}$ sodium acetate $(\mathrm{NaOAc})$ and $30 \mathrm{wt}-\%$ trifluoroethanol (TFE) in $10 \mathrm{mM}$ sodium acetate $(30$ wt-\% TFE/NaOAc) were used as the medium to evaluate the folding state of the peptides. As shown in Figure 3, peptide L1 exhibited a predominantly $\alpha$-helical structure not only in NaOAc solution, but also in $30 \mathrm{wt}-\% \mathrm{TFE} / \mathrm{NaOAc}$ solution. The later was usually used to mimic the membrane [11]. The CD spectra of $\mathrm{L} 1$ were characterized by distinct double minimum bands at both 208 and $222 \mathrm{~nm}$. This implied a higher $a$-helical content of L1. Other peptides exhibited disordered random coil in both conditions.

\section{Cytotoxicities}

The cytotoxicities of all the peptides were evaluated by their hemolytic toxixities toward rabbit red blood cells and the cytotoxic effects on mouse fibroblast cells. As shown in Table 2 and Figure 4, peptide $\mathrm{L} 1$ showed the highest hemolytic toxicity with $\mathrm{EC}_{50}$ values of $120 \mu \mathrm{g} / \mathrm{mL}$ among all the linear peptides, but was lower than Loloatin $\mathrm{C}(85 \mu \mathrm{g} / \mathrm{mL})$, in which the $\mathrm{EC}_{50}$ is defined as the concentration of peptides producing $50 \%$ hemolysis. Peptides with Orn displayed less toxicities, in which the $\mathrm{EC}_{50}$ values of both L1.2 and L3.2 were greater than $250 \mu \mathrm{g} / \mathrm{mL}$. When Pro in L1 was replaced by non-natural amino acids including Pip and Tic (entries L2, L2.1, L3, L3.1), the hemolytic toxicities were lowered down. On the other hand, as shown in Figure 5, all the peptides were non-toxic to mouse fibroblast cells at $62.5 \mu \mathrm{g} / \mathrm{mL}$ with cell viability more than $90 \%$. Even at a high concentration up to $250 \mu \mathrm{g} / \mathrm{mL}$, peptide L1 caused only $22 \%$ growth inhibition.
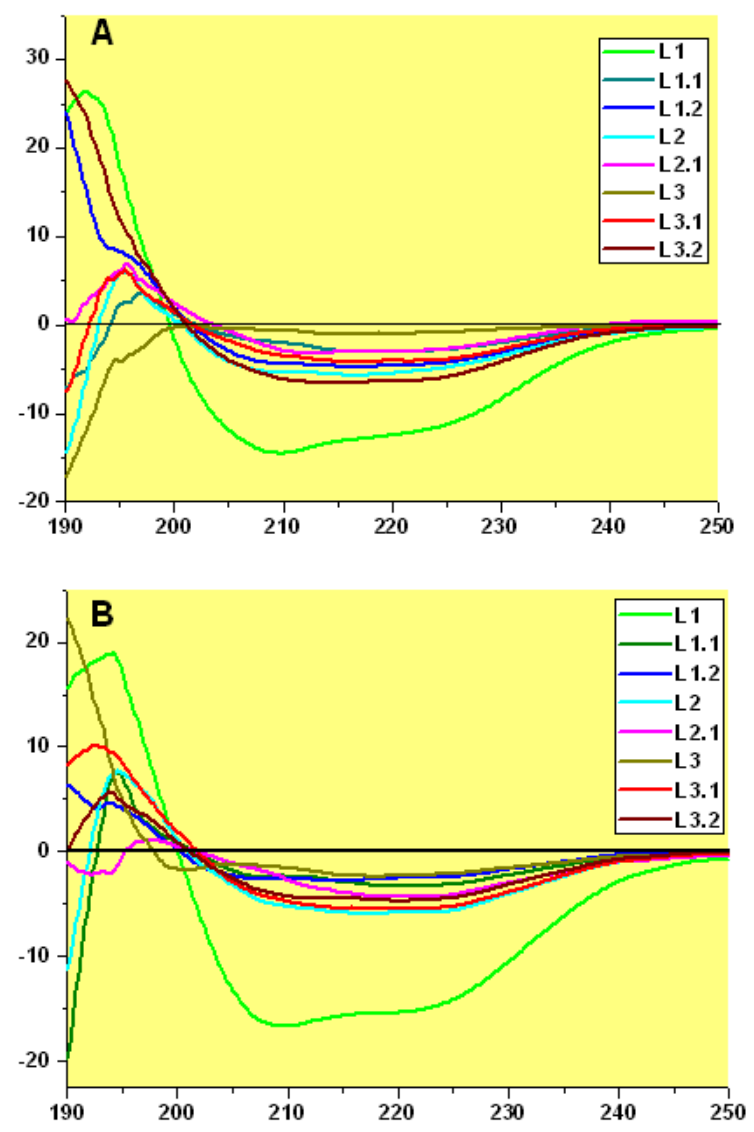

Figure 3: $\mathrm{CD}$ spectra of the peptides. (A) $10 \mathrm{mM} \mathrm{NaOAc}(\mathrm{pH} 5.5)$. (B) 30 wt-\% TFE in $10 \mathrm{mM} \mathrm{NaOAc}$ (pH 5.5).
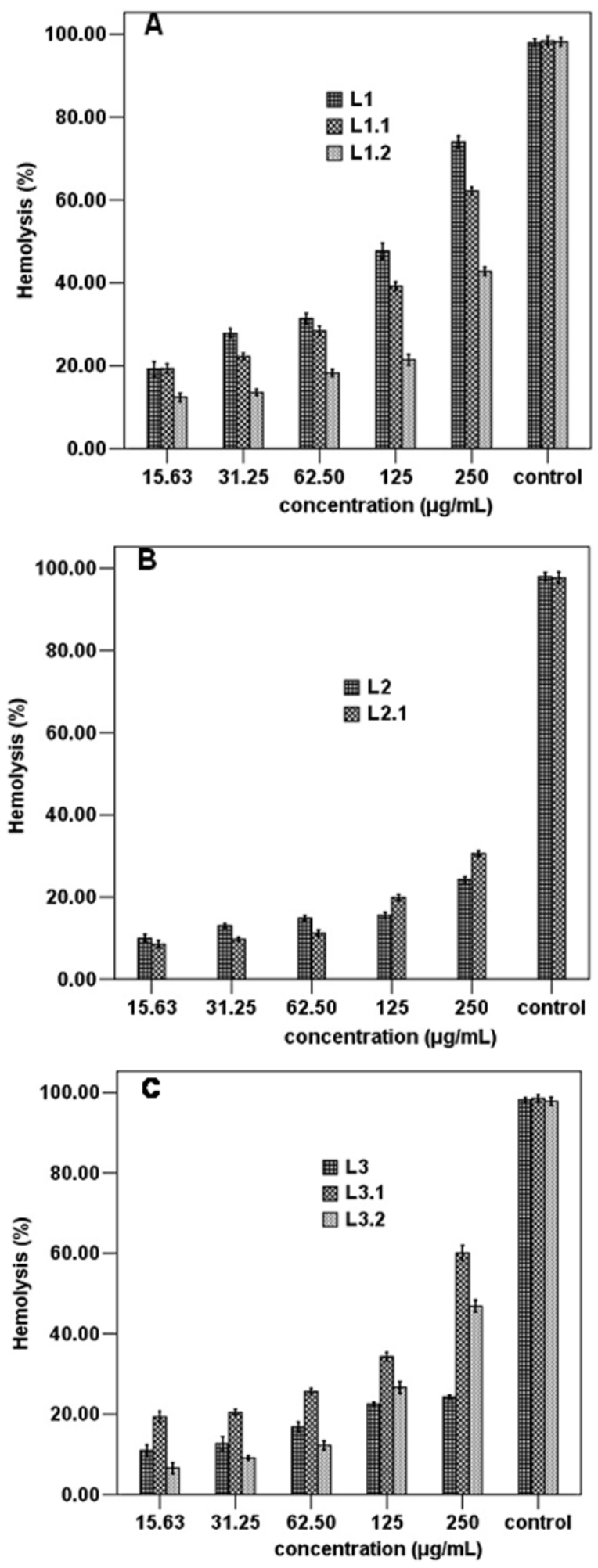

Figure 4: Hemolytic toxicities of the peptides against rabbit red blood cells. (A) Peptides L1, L1.1 and L1.2. (B) Peptides L2 and L2.1. (C) Peptides L3, L3.1 and L3.2. In $(\mathbf{A})$, significant differences $(p<0.001)$ were found between different concentrations vs control and different peptides L1, L1.1 and L1.2. In (B), significant difference $(p<0.001)$ was found between different concentrations vs control and no significant difference $(p>0.05)$ between peptides L2 and L2.1. In (C), significant differences $(p<0.001)$ were found between different concentrations vs control and different peptides L3, L3.1 and L3.2. 


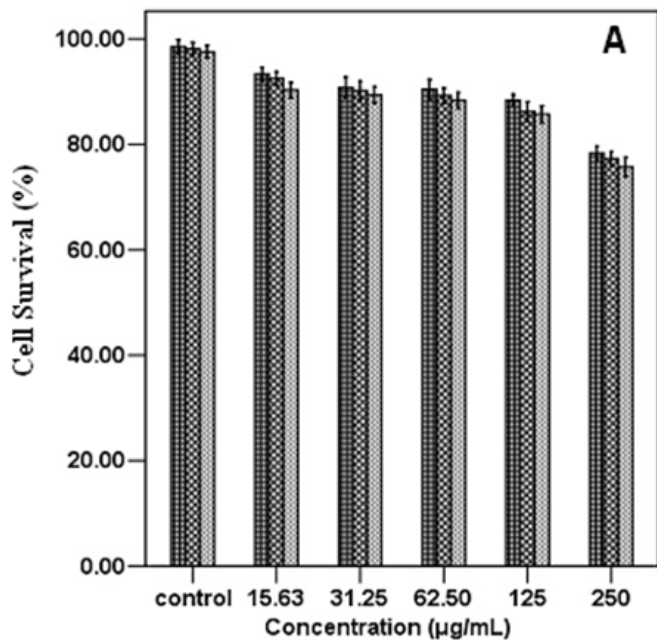

困 L1 $24 \mathrm{~h}$ 图 L1 $48 \mathrm{~h}$ 圆 L172h

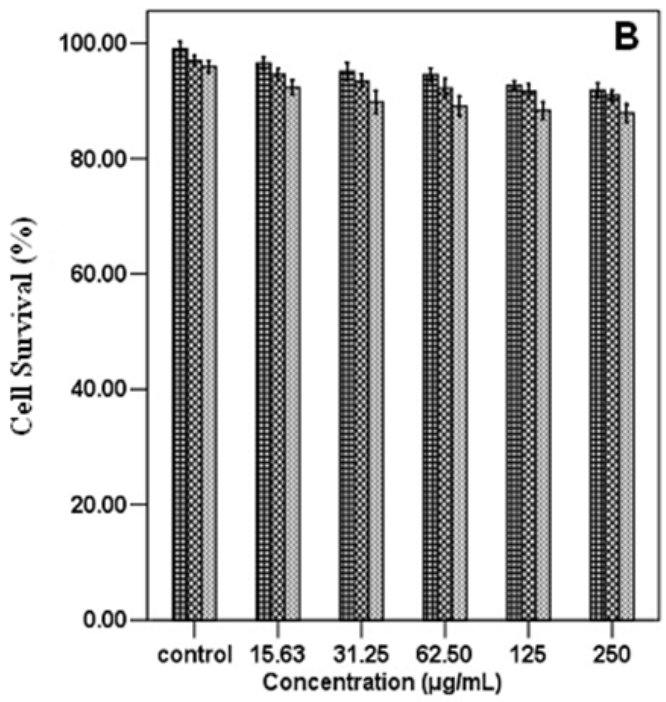

囲 L2 $24 \mathrm{~h}$

Q $L 248 h$

界2 $72 \mathrm{~h}$

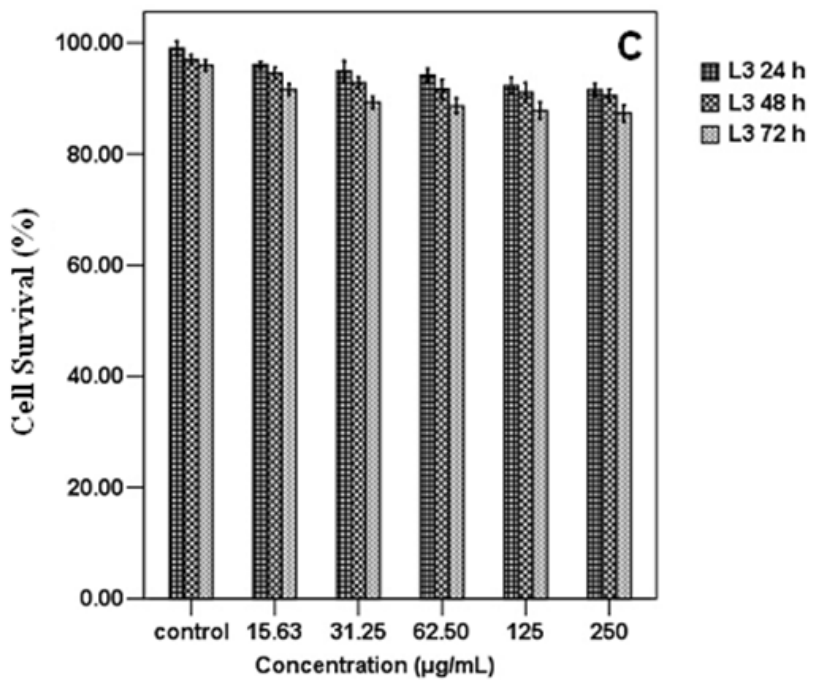

Figure 5: Cytotoxicity of peptides against mouse fibroblast cells. (A) The survive of the cells cultured with the peptide L1 after $24 \mathrm{~h}, 48 \mathrm{~h}$ and $72 \mathrm{~h}$. (B) The survive of the cells cultured with the peptide L2 after $24 \mathrm{~h}, 48 \mathrm{~h}$ and 72 h. (C) The survive of the cells cultured with the peptide L3 after $24 \mathrm{~h}, 48 \mathrm{~h}$ and $72 \mathrm{~h}$. In (A), (B), and (C), significant differences $(p<0.001)$ were found between different concentrations and different times $24 \mathrm{~h}, 48 \mathrm{~h}$ and $72 \mathrm{~h}$.

\section{Discussions}

Our previous work disclosed that Loloatin $\mathrm{C}$ possesses the striking dumbbell structure in the TFE/water solvent system, this makes the 'sliding window' analysis rather more attractive $[11,15]$. Through this method, the sequence -D-Tyr-Pro-Trp-D-Phe- was identified as the putative pharmacophore of Loloatin C. Normally, this sequence should be embodied in a cyclic molecular in order to maintain its activity. However, we put forward the idea that linear peptides containing the pharmacophore may be applied to mimic a complex cyclopeptide.

As shown in Table 3, although less active than Loloatin C, the short linear peptide L1 remain as a good antimicrobial candidate. It exhibits good activities toward gram-positive and gram-negative bacteria except fungus $C$. albicans, MRSA, and $K$. pneumoniae. L1 exhibits a-helix like domain conformation in $30 \mathrm{wt}$-\% trifluoroethanol (TFE) in $10 \mathrm{mM}$ sodium acetate solution (Figure 3 ) which is similar to lolatin $\mathrm{C}$ [11]. Actually, it is unusual for a short linear hexapeptide having a stable conformation in solution. Obviously, synthesis of L1 is far easier than that of Loloatin C. It is of note that L1 shows low hemolytic toxicity to rabbit red blood cell and low cytoticity to mouse fibroblast cells. Beyond doubt, L1 may be applied as a promising template for developing new antimicrobial agent.

The physicochemical properties, such as sequence, charge, hydrophobicity, amphipathicity, degree of structuring ( $\alpha$-helix, $\beta$-sheet and random coil content), size and the balance between the hydrophobic and polar regions were correlated with the antimicrobial activities [24-30]. In the current study, Pro has been confirmed a very important factor in maintaining the stable $\alpha$-helix like confroamtion and antimicrobial activity of L1. When Pro is replaced by Pip or Tic (L2 or L3), in which the small pyrrol ring in the main chain moves to a greater piperidine ring, the $\alpha$-helix-like conformation is lost, resulting in the decrease of activities. Interestingly, the hemolytic toxicities of both $\mathrm{L} 2$ and $\mathrm{L} 3$ also decrease when compared to that of $\mathrm{L} 1$.

Leu is considered a hydrophobic residue. This is confirmed by the fact that when Leu is inserted in the sequence, the $t_{R}$ value increases. However, the impact of Leu insertion is ambiguous. In case of L1, insertion of Leu (L1.1) lowers down its antimicrobial activity; while in L2, insertion of Leu (L2.1) leads to nuance of its activity; Surprisingly, insertion of Leu in L3 (L3.1) increases its antimicrobial activity. This indicates that the proper hydrophobicity is crucial for maintaining its antimicrobial activity, which is in accordance with the literatures [31,32].

On the other hand, Orn is a hydrophilic, basic, non-natural amino acids. Its structure is similar to Lys. Incorporation of Orn or Lys in a peptide sequence usually make it more hydrophilic and cation-charged. As reported in Gerard et al. [8], adding an additional positive charge on the hydrophilic face of Tyrocidine A (Figure 1) would arguably increase the analogues' affinity to the negative charged bacterial membrane, and markedly improves the antimicrobial properties especially toward gram negative E. coli. However, in the current study, insertion of Orn in L1 and L3 (L1.2 and L3.2) make their antimicrobial activities reduce dramatically; Simultaneously, their hemolytic toxicities to rabbit red blood cells and cytotoxicities to mouse fibroblast cells are greatly lowered down. The decrease of their cytotoxicities is reasonable because the incorporation of Orn makes the peptide more cationcharged which leads to higher affinity to bacterial membrane [8].

Although the putative pharmacophore of Loloatin $\mathrm{C}$ was deduced based on "sliding window" approach, it is satisfied with the minimal pharmacophore model established by Strom et al. [33]. It was reported 


\begin{tabular}{|c|c|c|c|c|c|c|c|}
\hline \multirow{2}{*}{ Entries } & \multicolumn{7}{|c|}{$\operatorname{MIC}(\mu \mathrm{g} / \mathrm{mL})^{a}$} \\
\hline & C. albicans & S. aureus & S. albus & MRSA & E. coli & K. pneumoniae & $P$. aeruginosa \\
\hline Loloatin $\mathrm{C}^{b}$ & 8 & 0.5 & - & 0.5 & 1.0 & - & $>32$ \\
\hline L1 & $>250$ & 15.6 & 15.6 & $>250$ & 15.6 & $>250$ & 31.2 \\
\hline L1.1 & $>250$ & 31.2 & 31.2 & $>250$ & 31.2 & $>250$ & 31.2 \\
\hline L1.2 & $>250$ & $>250$ & $>250$ & $>250$ & $>250$ & $>250$ & $>250$ \\
\hline L2 & $>250$ & 125 & 125 & $>250$ & 125 & $>250$ & 125 \\
\hline L2.1 & $>250$ & 125 & 125 & $>250$ & 125 & $>250$ & 125 \\
\hline L3 & $>250$ & 62.5 & 62.5 & $>250$ & 62.5 & $>250$ & 62.5 \\
\hline L3.1 & $>250$ & 31.2 & 31.2 & $>250$ & 31.2 & $>250$ & 31.2 \\
\hline L3.2 & $>250$ & $>250$ & $>250$ & $>250$ & $>250$ & $>250$ & $>250$ \\
\hline
\end{tabular}

a MIC: was defined as the lowest peptide concentration that showed no visible growth

${ }^{b}$ data from ref. (8); - means no data

Table 3: Antimicrobial Activities of the Peptides.

that the pharmacophore model in which activity against the Gramnegative bacterium Escherichia coli (E. coli) necessitates an amphipathic peptide with three bulky/lipophilic groups and two positively charged groups; For activity against the Gram-positive bacteria Staphylococcus aureus (S. aureus), MRSA and MRSE, the pharmacophore is even simpler by only necessitating an amphipathic peptide with two bulky/ lipophilic groups and two positively charged groups. Interestingly, it was disclosed further that the pharmacophore model for antistaphylococcal activity should contain bulky aromatic group larger than a benzyl group [34,35].

In the current research, the identified pharmacophore has three bulky aromatic groups and a weak positively charged group (Trp). This is why most of the peptides containing the sequence -D-Tyr-Pro-TrpD-Phe- exhibit activities against $S$. aureus, S. albus and Gram-negative bacteria $E$. coli strains with MIC values ranging from 15.6 to 62.5 $\mu \mathrm{g} / \mathrm{mL}$. It is a pity that even L1 shows inactive to fungus C. albicans, multi-drug resistant bacterium MRSA and K. pneumoniae. Whether if it needs to optimize the amount and position of the cation-charged residue is waiting for further investigation.

\section{Conclusion}

In summary, the sequence-D-Tyr-Pro-Trp-D-Phe- was identified as a promising pharmacophore model for developing antimicrobial agent. A short linear hexapeptide, H-Asp-D-Tyr-Pro-Trp-D-Phe-Asn$\mathrm{OH}(\mathrm{L} 1)$ is conformed as good mimics of the complex cyclodecapeptide Loloatin C. This is one successful example to simply a complex cyclopeptide to a short linear peptide. L1 shows stable $a$-helix domain conformation which is similar to Loloatin $\mathrm{C}$ in membrane-mimicing solution. All the peptides demonstrate low hemolytic toxicity to rabbit red blood cells with $\mathrm{EC}_{50}$ values higher than $120 \mu \mathrm{g} / \mathrm{mL}$ and low cytotoxicity to mouse fibroblast cells. The successful simplication of Loloatin C to a short linear peptide simplifies the synthetic process and lowers costs of production.

\section{Acknowledgments}

This work was supported by the National Natural Science Foundation of China (Nos. 30973565 and 81172982) and the Postdoctoral Scientific Foundation of China (No. 2013M531905)

\section{References}

1. Neu HC (1992) The crisis in antibiotic resistance. Science 257: 1064-1073.

2. Carlet J, Pittet $D(2012)$ Access to antibiotics: a safety and equity challenge for the next Sengupta S, Chattopadhyay MK. Antibiotic resistance of bacteria: a global challenge. Resonance 17: 177-191.

3. Boman HG (1995) Peptide antibiotics and their role in innate immunity. Annu Rev Immunol 13: 61-92.
4. Zasloff M (2002) Antimicrobial peptides of multicellular organisms. Nature 415 389-395.

5. Brown KL, Hancock RE (2006) Cationic host defense (antimicrobial) peptides Curr Opin Immunol 18: 24-30.

6. Mogi T, Kita K (2009) Gramicidin S and polymyxins: the revival of cationic cyclic peptide antibiotics. Cell Mol Life Sci 66: 3821-3826.

7. Marques MA, Citron DM, Wang CC (2007) Development of Tyrocidine A analogues with improved antibacterial activity. Bioorg Med Chem 15: 66676677.

8. Gerard JM, Haden P, Kelly MT, Andersen RJ (1999) Loloatins A-D, cyclic decapeptide antibiotics produced in culture by a tropical marine bacterium. $J$ Nat Prod 62: 80-85.

9. Tuin AW, Grotenbreg GM, Spalburg E, de Neeling AJ, Mars-Groenendijk RH et al. (2009) Structural and biological evaluation of some loloatin $C$ analogues. Bioorg Med Chem 17: 6233-6240.

10. Chen H, Haynes RK, Scherkenbeck J, Shi KH, Zhu G (2004) Elucidation of the solution conformations of Loloatin $C$ by NMR spectroscopy and molecular simulation. Eur J Org Chem 2004: 31-37.

11. Ding Y, Qin C, Guo Z, Niu W, Zhang R, et al. (2007) Solid-phase total synthesis and antimicrobial activities of loloatins A-D. Chem Biodivers 4: 2827-2834.

12. cherkenbeck J, Chen H, Haynes RK (2002) Solid-phase syntheses of Loloatins A-C. Eur J Org Chem 2350-2355.

13. Fares MA, Elena SF, Ortiz J, Moya A, Barrio E (2002) A sliding windowbased method to detect selective constraints in protein-coding genes and its application to RNA viruses. J Mol Evol 55: 509-521.

14. Rao N, Lei X, Guo J, Huang H, Ren Z (2009) An efficient sliding window strategy for accurate location of eukaryotic protein coding regions. Comput Biol Med 39: 392-395.

15. Chen H, Haynes RK, Scherkenbeck J (2004) Synthesis of cyclic hexapeptides based on the antibiotic cyclic decapeptide Loloatin $\mathrm{C}$ by an in situ indirect cyclization method. Eur J Org Chem 2004: 38-47.

16. Nokihara K, Nagawa Y, Hong SP, Nakanishi H (1997) Efficient solid-phase synthesis of a large peptide by a single coupling protocol with a single HPLC purification step. Lett Pept Sci 4: 141-146.

17. Amblard M, Fehrentz JA, Martinez J, Subra G (2006) Methods and protocols of modern solid phase Peptide synthesis. Mol Biotechnol 33: 239-254.

18. Kaiser E, Colescott RL, Bossinger CD, Cook PI (1970) Color test for detection of free terminal amino groups in the solid-phase synthesis of peptides. Anal Biochem 34: 595-598.

19. Vojkovsky T (1995) Detection of secondary amines on solid phase. Pept Res 8: 236-237.

20. Steinberg DA, Hurst MA, Fujii CA, Kung AH, Ho JF, et al. (1997) Protegrin-1: a broad-spectrum, rapidly microbicidal peptide with in vivo activity. Antimicrob Agents Chemother 41: 1738-1742.

21. Stark M, Liu LP, Deber CM (2002) Cationic hydrophobic peptides with antimicrobial activity. Antimicrob Agents Chemother 46: 3585-3590.

22. Fields GB, Noble RL (1990) Solid phase peptide synthesis utilizing 9-fluorenylmethoxycarbonyl amino acids. Int J Pept Protein Res 35: 161-214. 
Citation: Guo C, Pan L, Xiao S, Chen H, Jiang Z (2014) Short Simple Linear Peptides Mimic Antimicrobial Complex Cyclodecapeptides Based on the Putative Pharmacophore. Med chem 4: 322-329. doi:10.4172/2161-0444.1000159

23. Schmitt MA, Weisblum B, Gellman SH (2007) Interplay among folding, sequence, and lipophilicity in the antibacterial and hemolytic activities of alpha/ beta-peptides. J Am Chem Soc 129: 417-428.

24. Jahnsen RD, Frimodt-MÃ,ller N, Franzyk H (2012) Antimicrobial activity of peptidomimetics against multidrug-resistant Escherichia coli: a comparative study of different backbones. J Med Chem 55: 7253-7261.

25. Huang Y, Huang J, Chen Y (2010) Alpha-helical cationic antimicrobial peptides: relationships of structure and function. Protein Cell 1: 143-152.

26. Kim SJ, Kim JS, Lee YS, Sim DW, Lee SH, et al. (2013) Structural characterization of de novo designed L5K5W model peptide isomers with potent antimicrobial and varied hemolytic activities. Molecules 18: 859-876.

27. Hicks RP, Abercrombie JJ, Wong RK, Leung KP (2013) Antimicrobial peptides containing unnatural amino acid exhibit potent bactericidal activity against ESKAPE pathogens. Bioorg Med Chem 21: 205-214.

28. Teixeira V, Feio MJ, Bastos M (2012) Role of lipids in the interaction of antimicrobial peptides with membranes. Prog Lipid Res 51: 149-177.

29. Leite NB, da Costa LC, Dos Santos Alvares D, Dos Santos Cabrera MP, de Souza BM, et al. (2011) The effect of acidic residues and amphipathicity on the lytic activities of mastoparan peptides studied by fluorescence and $C D$ spectroscopy. Amino Acids 40: 91-100.

30. Kang SJ, Kim DH, Mishig-Ochir T, Lee BJ (2012) Antimicrobial peptides: their physicochemical properties and therapeutic application. Arch Pharm Res 35: 409-413.

31. Rao AG (1999) Conformation and antimicrobial activity of linear derivatives of tachyplesin lacking disulfide bonds. Arch Biochem Biophys 361: 127-134.

32. Lee JU, Kang DI, Zhu WL, Shin SY, Hahm KS, et al. (2007) Solution structures and biological functions of the antimicrobial peptide, arenicin-1, and its linear derivative. Biopolymers 88: 208-216.

33. Strom MB, Haug BE, Skar ML, Stensen W, Stiberg T, et al. (2003) The pharmacophore of short cationic antibacterial peptides. J Med Chem 46: $1567-$ 1570.

34. Haug BE, Stensen W, Stiberg T, Svendsen JS (2004) Bulky nonproteinogenic amino acids permit the design of very small and effective cationic antibacterial peptides. J Med Chem 47: 4159-4162.

35. Hansen T, Alst T, Havelkova M, StrÃ m MB (2010) Antimicrobial activity of small beta-peptidomimetics based on the pharmacophore model of short cationic antimicrobial peptides. J Med Chem 53: 595-606. 